\title{
Traffic Crime Law Enforcement On Over Dimensions
}

\author{
Yunanto Dwi Handoko*) and Maryanto**) \\ *) Police at Polrestabes, Semarang, Indonesia E-mail: \\ yunanto mh36@std.unissula.ac.id \\ ${ }^{* *}$ ) Faculty of Law Universitas Islam Sultan Agung
}

\begin{abstract}
The purpose of this study describes how the law enforcement of Act No. 22 of 2009 concerning Road Traffic and Transportation against over-dimensions as well as obstacles and solutions in overcoming public transportation law enforcement that is OverDimensional. The approach method used in this research is empirical juridical. Based on the research, it can be concluded that law enforcement in over-dimensional cases is contained in the provisions for the mandatory testing of types of public transportation vehicles or overdimensional vehicles regulated in Act No. 22 of 2009 concerning Road Traffic and Transportation. In addition to Act No. 22 of 2009 concerning Road Traffic and Transportation, there is also Government Regulation Number 55 of 2012. Over-dimensional vehicles are strictly prohibited because in the event of a traffic accident, the fatality of the victim is very high. The over-dimension does not take into account the factors of security, safety and order and the smoothness of traffic, and only cares about the profits of public transport entrepreneurs, so they must be punished in accordance with the applicable laws and regulations.
\end{abstract}

Keywords: Law Enforcement; Over Dimension; Traffic Accidents.

\section{Introduction}

Transportation is a means needed by Indonesian people in their daily life. This transportation is very much needed by the Indonesian people because of many factors including, the geographical condition of Indonesia which consists of thousands of islands, the waters which are mostly in the form of oceans which encourage transportation by land, sea and air to reach the territory of the Unitary State of the Republic of Indonesia. All of that is also for the sake of survival for every community in Indonesia, because without transportation it will complicate the existing life process. ${ }^{1}$

Road transportation is the main transportation capital that plays an important role in supporting national development and has the largest contribution in the transportation nation compared to other capital. Therefore, the vision of road transportation is to support, drive and encourage national development and act as the lifeblood of economic, political, socio-cultural and defense and security life. The mission of road transportation is to create a road transportation system that is reliable, highly capable in development and improves mobility of people and goods, in order to support regional development to realize an archipelago insight.

The increasing population and growing economy in developing countries such as Indonesia require people to have high mobility in order to meet their daily

\footnotetext{
${ }^{1}$ Abdulkadir Muhammad, 1998, Hukum Pengangkutan Niaga, Citra Aditya Bakti, Bandung, p.7
} 
needs. To be able to have high mobility, people certainly need transportation tools or facilities, besides that currently transportation tools are widely used by people. Public transportation is land transportation, namely private transportation and public transportation. In the 1945 Constitution Article 34 paragraph 3 states that "The state is responsible for the provision of health service facilities and proper public service facilities".

According to Soetjipto Rahardjo, the factors that influence law enforcement are social processes that involve the human environment, socio-political culture. So law enforcement is influenced by various kinds of reality and conditions that occur in society. The description of the description is that humans in living their lives will always need needs that are complementary in living their life processes. Needs are an embodiment of human culture with the dimensions of creativity, initiative, and taste. ${ }^{2}$

One of the factors that contributed to the increase in the fatality rate of traffic accidents was the involvement of transport vehicles which in the process of investigating traffic accidents proved to have experienced technical malfunctions, both failure of the brake system and failure of vehicle stability control. The failure of the technical function of the transportation vehicle is not only caused by not optimal maintenance but also due to a violation of the technical specifications that have been determined. ${ }^{3}$ This causes the transportation vehicle to become overdimensional which has the potential to become overloaded to pursue business profits by ignoring the safety factor. Unfortunately, the problems mentioned above have never been seriously discussed so that violations of technical specifications have become rampant which has resulted in many transportation vehicles being unsafe.

The Directorate General of Land Transportation of the Ministry of Transportation as the regulator in this matter has also not been able to optimally carry out prevention efforts through supervision and control activities considering the disconnection of the chain of command with the Regency/City Transportation Service as the operator implementing the issuance of the keur book as proof of the validity of the operation of transportation vehicles. ${ }^{4}$

Public transportation is a very popular means of transportation in Indonesia. The development of public transportation in Indonesia differs from one region to another. Along with technological developments, public transportation began to be modified according to the needs in cubication (number of goods loaded) without considering the factors of security, safety and order and traffic smoothness, hereinafter referred to as over-dimensional.

Over-dimensional vehicles are strictly prohibited because the transportation does not take into account the factors of security, safety and order and smooth traffic, and only prioritizes the profits of public transport entrepreneurs. From the

\footnotetext{
${ }^{2}$ Supriadi, Etika dan Tanggung Jawab Profesi Hukum di Indonesia, Sinar Grafika, Jakarta, p. 3.

${ }^{3}$ In the process of changing the shape of the vehicle, the body of the body must be guided by the Design and Build Decree (SKRB) issued by the Directorate General of Land Transportation, Ministry of Transportation.

4 The Directorate General of Land Transportation, Ministry of Transportation expressed appreciation and gratitude to the Traffic Unit of Semarang Polrestabes for carrying out traffic crime investigations in the case of overdimensional criminal acts.
} 
explanation above, there are still many motorized public transport vehicles operating on public roads and the lack of security in motorized public transport vehicles, especially in the city of Semarang.

The objectives of this research are: How is the law enforcement of Act No. 22 of 2009 concerning Road Traffic and Transportation against over-dimension? What are the obstacles and solutions in overcoming the Over Dimensional law enforcement of public transport?

\section{Research Methods}

The approach method used in this research is empirical juridical. The specifications in this study are analytical descriptive which aims to determine law enforcement efforts against "Over Dimension" traffic crimes in the Order of Traffic Order. The data collection method used is literature study, which is a way of obtaining data indirectly from the object of research in the form of studying literature, legislation, and other legal materials that are closely related to the title of the study.

Field studies in this case attempted to obtain data by conducting interviews with various parties related to the research title. The data analysis method used is qualitative. The data obtained were collected and compiled systematically and then carried out a qualitative data analysis based on legal disciplines and assisted by other social sciences which were then applied in the form of research writing. In addition, only research results that are deemed relevant will be selected to draw up the final conclusions.

\section{Results and Discussion}

Criminal law in criminal law is a tool and not a goal of criminal law, which if implemented is nothing but suffering or discomfort for the person concerned, called the convict. The main purpose of criminal law is that special order can be called the prevention of the community from being raped against protected legal interests.

Law enforcement in modern society is not only interpreted in a narrow sense but also in a broad sense, as in Indonesia law enforcement is associated with the human element and the social environment. ${ }^{5}$ Law enforcement efforts are in line with the principles of the Unitary State of the Republic of Indonesia, namely Pancasila. The enforcement of the law is a prerequisite for a state of law, law enforcement always involves humans in it and thus will involve human behavior as well. Criminal law enforcement efforts are essentially also part of law enforcement efforts and are often referred to as politics or criminal law policies which are part of law enforcement policies. ${ }^{6}$

\footnotetext{
${ }^{5}$ Barda Nawawi Arief, Bunga rampai Kebijakan Hukum Pidana, PT. Citra Aditya Abadi, Jakarta 1996, p. 29.

6 M. Dani Hamzah, Penegakan hukum pada kasus tindak pidana kecelakaan lalu lintas yang menyebabkan hilangnya nyawa orang, Jurnal Hukum Vol.I accessed from http://jurnal.unissula.ac.id/index.php/RH/article/view/2563/1920 on July 11, 2021.
} 
Public transportation is in the form of four-wheeled vehicles, people also use other alternative transportation in the form of motorcycle taxis and public transportation. Public transportation is a very popular means of transportation in Indonesia. The development of public transportation in Indonesia differs from one region to another. Along with technological developments, public transportation began to be modified according to the needs in cubication (number of goods loaded) without considering the factors of security, safety and order and smooth traffic, hereinafter referred to as over-dimension. The definition of Over Loading is divided into 2 (two) words, Over which means "more" while Loading which means "loading, loading, loading", so that Over Loading is defined as excess in loading, loading, loading of goods being transported. Provisions regarding the obligation to test the type of public transport vehicle or overdimensional vehicle are regulated in Act No. 22 Of 2009 concerning Road Traffic and Transportation. In addition to Act No. 22 of 2009 concerning Road Traffic and Transportation, there is also Government Regulation Number 55 of 2012. The provisions for the technical requirements of motorized vehicles contained in Act No. 22 of 2009 concerning Road Traffic and Transportation are contained in Article 50, namely: Provisions regarding the obligation to test the type of public transport vehicle or overdimensional vehicle are regulated in Act No. 22 Of 2009 concerning Road Traffic and Transportation. In addition to Act No. 22 of 2009 concerning Road Traffic and Transportation, there is also Government Regulation Number 55 of 2012. The provisions for the technical requirements of motorized vehicles contained in Act No. 22 of 2009 concerning Road Traffic and Transportation are contained in Article 50, namely:

(1) The type test as referred to in Article 49 paragraph (2) letter a must be carried out for every Motor Vehicle, trailer, and patch carriage, which is imported, manufactured and/or assembled domestically, as well as the modification of the Motor Vehicle which causes a change in type. .

(2) The type test as referred to in paragraph (1) consists of:

a. Physical testing for the fulfillment of technical and roadworthy requirements carried out on the base of Motorized Vehicles and Motorized Vehicles in a complete condition; and

b. Research on the design and engineering of Motor Vehicles carried out on houses, cargo tanks, trailers, patch trains, and modified types of Motorized Vehicles.

The provisions regarding Article 1 number 12 in Government Regulation Number 55 of 2012 concerning vehicles (PP No. 55/2012), explain that motor vehicle modification is a change to the technical specifications of dimensions, engines, and/or the carrying capacity of motorized vehicles. Based on this, it is explained that every party who wants to modify his or her motorized vehicle is required to have a permit for the modification as required in Act No. 22 of 2009 concerning Road Traffic and Transportation.

If the modification is done without a permit and without passing the type test, then based on Act No. 22 Of 2009 concerning Road Traffic and Transportation: Article 277 reads; Any person who imports a Motor Vehicle, trailer, and patch carriage into the territory of the Republic of Indonesia, manufactures, assembles, or modifies a Motor Vehicle that causes a change in the 
type, trailer, patch carriage, and special vehicle operated domestically that does not fulfill the obligations type test for roadworthiness, quality test and endurance test as referred to in Article 50 paragraph (1) shall be punished with imprisonment for a maximum of 1 (one) year or a fine of a maximum of IDR 24,000,000.00 (twenty four million rupiah).

Based on the results of the investigation carried out by the Semarang Police in the case of over-dimensional public transport law enforcement, there is a modus operandi in this case, namely the owner of the transportation deliberately changes the dimensions that are not in accordance with the SKRB (Decree on Design and Construction) determined from the Ministry of Transportation and the body of the body that does not make dimensions that are not in accordance with the SKRB and do not register the vehicle for submission of SRUT (Type Test Registration Certificate). ${ }^{7}$ The need for inter-agency cooperation is an important key in overdimensional prosecution because without it it will be difficult to obtain evidence of the case.

Traffic accidents generally occur due to various causative factors such as negligence of road users, vehicle unfitness, and road and or environmental unfitness in addition to that. The community's indiscipline in traffic has resulted in many traffic violations which are quite high and the ownership of private vehicles is increasing day by day, this will indirectly trigger traffic accidents. According to Article 229 Act No. 22 of 2009 concerning Road Traffic and Transportation in the form of traffic accidents is divided into 3 categories as follows:

- Minor traffic accidents are accidents that result in damage to vehicles and/or goods.

- Moderate Traffic Accidents are accidents that result in minor injuries and damage to vehicles and/or goods.

- A serious traffic accident is an accident that results in the victim's death or serious injury.

The cause of many traffic accidents is from several factors, namely human factors, vehicle factors, road factors and natural factors (weather). The vehicle factor is one of the most influential factors on the fatality of traffic accident victims on the highway, therefore the over dimensional action of public transport aims to reduce the fatality of traffic accident victims. Legal awareness is very influential in preventing violations of the law, in this case traffic and road transportation violations should not be carried out because they will harm other people, society and the state. ${ }^{8}$ The implementation of over-dimensional public transport law enforcement has several obstacles when applied in the field, but there are still solutions to overcome these obstacles, the following are the obstacles and solutions, including:

- Coordination, collaboration and communication with Related Agencies (Ministry of Transportation, Prosecutor's Office, Courts, Practitioners in the field of Transportation and University Academics in the field of Law) are

\footnotetext{
${ }^{7}$ Data on the prosecution of criminal acts over the dimensions of the Semarang Polrestabes in 2020.

${ }_{8}$ Meta Suryani, Penegakan hukum terhadap becak bermotor umum(bentor) berdasarkan undangundang nomor 22 tahun 2009 tentang lalu lintas dan angkutan jalan, Jurnal Hukum Vol.III accessed from http://jurnal.unissula.ac.id/index.php/PH/article/view/1341/1035 on July 4, 2021.
} 
obstacles and keys in implementing over-dimensional public transport law enforcement.

- Case Over-dimensional law enforcement of public transportation is a new thing in Indonesia since the enactment of Act No. 22 of 2009 concerning road traffic and transportation in 2021, the case can be P21 so it needs a lot of socialization to the CJS (criminal justice system) in the implementation over-dimensional public transport law enforcement.

- From the investigation budget, there is also no budget so that in the future it is necessary to have a special budget in the implementation of over-dimensional public transport law enforcement.

\section{Closing}

Enforcement of over-dimensional public transport laws is essentially when someone commits modifications are made without having a permit and without passing a type test, then based on Act No. 22 of 2009 concerning Road Traffic and Transportation.The case of over-dimensional public transport law enforcement is a new thing in Indonesia since the enactment of Act No. 22 of 2009 concerning road traffic and transportation in 2021, the case can be P21 so it needs a lot of socialization to the CJS (criminal justice system) in implementation of overdimensional public transport law enforcement. From the investigation budget, there is also no budget so that in the future it is necessary to have a special budget in the implementation of over-dimensional public transport law enforcement.

\section{References}

\section{Journal}

[1] M. Dani Hamzah, Penegakan hukum pada kasus tindak pidana kecelakaan lalu lintas yang menyebabkan hilangnya nyawa orang, Jurnal Hukum Vol.I accessed from http://jurnal.unissula.ac.id/index.php/RH/article/view/2563/1920 on July $11,2021$.

[2] Meta Suryani, Penegakan hukum terhadap becak bermotor umum(bentor) berdasarkan undang-undang nomor 22 tahun 2009 tentang lalu lintas dan angkutan jalan, Jurnal Hukum Vol.III accessed from http://jurnal.unissula.ac.id/index.php/PH/article/view/1341/1035 on July 4, 2021.

\section{Book}

[1] Abdulkadir Muhammad, 1998, Hukum Pengangkutan Niaga, Citra Aditya Bakti, Bandung

[2] Barda Nawawi Arief, Bunga rampai Kebijakan Hukum Pidana, PT. Citra Aditya Abadi, Jakarta 1996

[3] Supriadi, Etika dan Tanggung Jawab Profesi Hukum di Indonesia, Sinar Grafika, Jakarta

\section{Regulation}

\section{[1] Criminal Procedure Code}


[2] Criminal Code

[3] Act No. 2 of 2002 National Police of the Republic of Indonesia,

[4] Act No. 22 of 2009 concerning Road Traffic and Transportation

[5] Government Regulation No. 55 of 2012 concerning Vehicles

\section{Others:}

[1] Data on the prosecution of criminal acts over the dimensions of the Semarang Polrestabes in 2020.

[2] Design and Build Decree (SKRB) issued by the Directorate General of Land Transportation, Ministry of Transportation.

[3] The Directorate General of Land Transportation, Ministry of Transportation expressed appreciation and gratitude to the Traffic Unit of Semarang Polrestabes for carrying out traffic crime investigations in the case of overdimensional criminal acts. 